\title{
Effect of Saffron (Crocus sativus) on Obese Rats
}

\section{Eman M. Mokbl', Elham M. Mahmod ${ }^{1}$, Abd El- Aziz N. Shehata ${ }^{2}$ and Hala M. Ali ${ }^{1}$}

\author{
${ }^{I}$ Nutrition and Food Science Dept., Faculty of Home Economics, Helwan University, Egypt. \\ ${ }^{2}$ Food Technology Dept., National Research Centre, 33 El-Buhouth St., 12622 Dokki, Giza, Egypt
}

Received: 15 April 2020 / Accepted 10 June 2020 / Publication date: 15 August 2020

\begin{abstract}
Obesity is characterized by an excessive fat accumulation of adipose tissue that is accompanied by the development and progression of some diseases, such as cardiovascular diseases. The mechanisms that link obesity with cardiovascular. Saffron (Crocus sativus L.) is a popular Iranian additive. Which its beneficial effects on several diseases have been found in previous studies. Although several studies have investigated the effect of saffron supplementation on obesity, serum glucose and lipids concentrations, findings are inconsistent. Saffron supplementation has significantly reduced blood glucose and lipid profiles. The interesting on natural components of plants is increasing due to their association with health benefits. The potential effect saffron on body weight, serum Lipid profile, liver and kidney functions was investigated in obese rats, twenty nine male albino rats $(180+10)$ allocated into: G1- standard group: rats fed on normal standard diet . G2- was only fed on HFD as a control positive group its number were 8 rats was slaughter at the seven week from experience and weight the accumulated fat percent with liver, kidney, heart and stomach which was $2.6 \%$. G 3- HFD + supplemented with $2 \%$ saffron and G-4 HFD $+5 \%$ saffron powder, respectively. The result indicated that supplementation with saffron. Were significantly decreased $(\mathrm{P}<0.05)$ body weight of the obese rats compared to the control positive group. Moreover, serum cholesterol, triglycerides, LDL-c, VLDL-c, uric acid, creatinine, AST and ALT were significantly decreased $(\mathrm{P}<0.05)$ in treated group fed on 5\% saffron, while serum HDL-c was significantly increased $(\mathrm{P}<0.05)$ as compared to control positive group. The effective result was found in the $5 \%$ saffron .These data suggest that saffron supplementation may provide beneficial effects in body weight reduction as well as improving lipid profile, liver and kidney function and serum glucose in obese rats.
\end{abstract}

Keywords: saffron (Crocus sativus), High fat diet, obesity and rats

\section{Introduction}

Obesity is defined as excess accumulation of body fat and is known as a low grade inflammation condition (Mohammed et al., 2014). Obesity, not only affect the body image and self-esteem but also it is associated with increased risk for numerous chronic diseases, including hypertension, insulin resistance, type 2 diabetes and cardiovascular disease (Haidari., et al., 2014). Therefore, it is important to find a safe and effective way to manage body weight especially in obese patients. Weight management is a long-standing goal of achieving a healthy life that is including healthy eating and physical activity to maintain a balance between intake and energy consumption (Dunn 2015).

Filaments of saffron are made from the dried and dark red stigmas of (Crocus sativus L.) flowers (an autumn-flowering geophyte) belonging to the (Iridaceous) family. Za'afarn is the original Persian name of saffron, meaning yellow flowers (Ramadan et al., 2010). Also, since it is the most expensive spice in the whole world, saffron has been named 'red gold'. Another point is that harvesting and postharvest operations are normally performed without mechanical equipment; in fact picking of saffron flowers is done daily by hand, lasting only 2 to3 weeks (Molina, and García 2005).

Saffron is a rich source of carotenoids (crocin), glycoside (picrocrocin) and a volatile oil component (safranal) (Fernández and Pandalai, 2004; Winterhalter and Straubinger, 2000).

Chemical analysis has shown the presence of more than 150 components in saffron stigmas, which contain lipophilic and hydrophilic carbohydrates, proteins, amino acids, minerals,mucilage,starch,gums, vitamins (especially riboflavin and thiamine), pigments (crocin, alfa and beta carotenes, mangicrocin, xanthone carotenoid glycosidic conjugate, anthocyanin, lycopene, flavonoids and zeaxanthin), alkaloids, saponins, saffranal (aromatic essence terpene)

Corresponding Author: Eman M. Mokbl, Nutrition and food science Dept., Faculty of Home Economics, Helwan University, Egypt. 
and picrocrocin (bitter flavor) together with other chemical compounds (Samarghandian and Borja, 2014; Zarinkamar et al., 2011). The main components of stigma are crocetin, its glucosidic derivatives, crocins, picrocrocin, safranal (Rubio et al., 2010) and flavonoids including quercetin and kaempferol (Pitsikas et al., 2007).

Stigma of (Crocus sativus) flower, also known as saffron, has been utilized as functional food in prevention of diseases. Biological and pharmacological properties of saffron and its active constituent, and their possible therapeutic uses for a broad range of diseases have been extensively examined (Christodoulou et al., 2015).

Antioxidants, improve learning and memory, be used for treatment of cerebral infarction and neurodegenerative damage, and have a protective effect against ischemic brain damage (Nescatelli et al., 2017).

The plant's stigmas have been used for centuries in herbal medicine, known for their antioxidant properties (Christodoulou et al., 2015). In parallel, an increasing number of research studies on the possible clinical uses of saffron have been conducted, especially against malignancies (Bolhassani et al., 2014), cardiovascular (Efentakis et al., 2017) and Alzheimer's diseases (Akhondzadeh et al., 2010).

Since obesity increases peripheral serotonin (de Matos et al., 2011), the suppression of serotonin signaling or its formation in fat tissue might be an effective approach for obesity treatment and its comorbidity. Crocin is a herbal carotenoid that constitutes the main component of the Crocus sativus flower known as saffron. It is a made from the disaccharide gentiobiose and the dicarboxylic acid crocetin. Crocin or saffron extract has been shown to possess several health properties (Christodoulou et al., 2015) such as antioxidant (Chen et al., 2008). Hypolipidaemic, hypotensive (Imenshahidi et al., 2010), hypoglycaemic (Mohajeri et al., 2009) and satiety enhancer effects (Gout et al., 2010).

Saffron has various pharmacological effects and is regarded as a potent drug. Thus research on the biological activities of saffron and its active constituents may have clinical and public health application. The main active constituents of this plant are crocetin, safranal, picrocrocin and crocins (Trantilis et al., 1995). Saffron is used in folk medicine as an anticatarrhal, antispasmodic, gingival sedative, nerve sedative, carminative, diaphoretic and expectorant (Riose et al., 1996).

In modern pharmacological studies, saffron or its active constituents has demonstrated antiinflammatory, anti-oxidant (Kanakis et al., 2007), hypolipidaemic, insulin resistance reducing (Xi et al., 2005), tissues oxygenation enhancing (Gainer et al., 1993) and hypoglycemic (Mohajeri et al., 2009) effects. Recently, it was found that saffron extract, crocin and safranal exhibited significant radical scavenging activity and thus antioxidant activity (Assimopoulou et al., 2005).They indicated that, crocin had lipid lowering properties and selectively inhibits the activity of pancreatic lipase as a competitive inhibitor.

\section{Materials and Methods}

\section{Plant}

Saffron were obtained from area of city (Haraz Bab El Khalq. Cairo, Egypt).Corn starch, Casein, saturated fat, Corn oil, Sucrose, Cellulose, Mineral mix, Vitamin mix, DL-methionine, Choline bitarate were obtained from El- Gomhoria Company pharm. Cairo, Egypt.

\section{Preparation of saffron}

The herb materials saffron were ground to a $1.3-1.5 \mathrm{~mm}$ size particle and were stored protected from the light at room temperature. Infusions were prepared by adding $200 \mathrm{ml}$ of freshly boiled water to $2 \mathrm{~g}$ of dried ground sample; then the infusion was allowed to steep for $15 \mathrm{~min}$ and was finally filtered and added to the diet at different levels, Gray et al., (2000).

\section{Animals}

The experiment was carried out on twenty nine adult male albino rats Sprague- Dawley strain $(180 \pm 10 \mathrm{~g})$ were obtained from the animal house of Research institute of ophthalmology, Giza. were housed in wire aerated cages separately under the hygienic laboratory conditions and were fed on basal diet for a week as an adaptation period. Diet was offered to rats in special feed cups to avoid looser condition of food, water was provided to the rats by glass tubes supported to one side of the 
cage. Feed and water provided ad-libtium and checked daily (Jennings et al., 1974). All experiments were carried out according to the ethical guidelines approved by the Ethical committee of NRC (1993).

The induction of the obesity was carried out by the feeding of the High Fat Diet (HFD) in table (1) for 4 weeks saturated fat $40.0 \%$, corn oil $5.0 \%$ to provide essential fatty acids, casein $20.0 \%$ cellulose $0.20 \%$ and the remainder is corn starch $15.0 \%$, L.cysteine $0.30 \%$, sucrose $15.0 \%$ ( Maryam et al., 2017).

\section{Chemical analysis of saffron}

The chemical composition and active components of the saffron in table (2) were determined by (Micro-kjeldahl apparatus as described in the A.O.A.C. (2005).

\section{Experimental Design}

Animals were allocated into four groups, each of seven animals except the group fed on HFD only were eight rats as follow:

G 1: (Standard group): rats fed with normal standard diet Table (1) Maryam et al., 2017, G 2:( HFD group): rats fed with a high fat-diet (HFD), G 3 (HFD+ Saffron): rats fed with HFD and received saffron $(0.025 \mathrm{ml} / \mathrm{kg}$ of BW daily), G 4.(HFD+ saffron): rats fed with HFD and received saffron $(0.050 \mathrm{ml} / \mathrm{kg}$ of BW daily)(Vogel, 2002).

Table 1: Formulations of normal and high-fat diets. According to Maryam et al., 2017

\begin{tabular}{lcc}
\hline Ingredient & Normal diet (g/kg diet) & (g/kg diet) \\
\hline Corn starch & 65.00 & 15.00 \\
Casein & 20.00 & 20.00 \\
Saturated fat & 0.00 & 40.00 \\
Corn oil & 5.00 & 0.00 \\
Sucrose & 0.00 & 15.00 \\
Fibers & 5.00 & 5.00 \\
Mineral mix & 3.50 & 3.50 \\
Vitamin mix & 1.00 & 1.00 \\
L-cysteine & 0.30 & 0.30 \\
Choline bitarate & 0.20 & 0.20 \\
\hline Total & 100 & 100 \\
\hline
\end{tabular}

\section{Biological evaluation}

Feed intake (FI), were recoded daily and animals body weight gain (BWG), were weighed at the beginning and twice a week throughout the experimental period. Body weight gain and feed efficiency ratio (FER) were calculated at the end of the experiment according to the method of (Fritzberg et al., 1986).

$\mathrm{FER}=$ Gain Weight $/$ feed consumed $\mathrm{BWG}=$ final body

Weight-initial body weight/Initial body weight $\times 100$

\section{Peritoneal fat pad}

At the end of experimental period ( 7 weeks), peritoneal fat pad was dissected from the rats , then weighed and stored at $-20 \mathrm{C}$ according to the methods of Azain et al., (2000) peritoneal fat bad were be measured in research institute of ophthalmology. The percentage of peritoneal fat bad was calculated as follows:

$$
\frac{\text { Weight of peritoneal fat pad }(7 \mathrm{~g})}{\text { Weight of rat }(260 \mathrm{~g})} \times 100=2.6 \%
$$

\section{Blood sampling and Biochemical analysis}

Blood sampling is carried out by open heart puncture under slight ether anesthesia, note: (animals were fasted overnight), then centrifugation for 10 minutes at 3500 r.p.m. serum was separated and kept at $-20 \mathrm{EC}$ till used in chemical analysis. 
Collected serum was analyzed to determine the following parameters: Serum cholesterol Allain et al., (1974), triglycerides Interference testing in clinical chemistry (2005), HDL-C, LDL-C and VLDL-C according to (Stienberg,1981), glucose (Sacks, 2008), aspartate amino transferase (AST) and alanine amino transferase(ALT), (Young, 2001) and (Brasil ,1999), uric acid (Vassault,1986), urea and creatinine,(Berth and Delanghe,2004).

\section{Statistical Analysis}

Data was presented as means \pm SD statistically analyzed using one way ANOVA test, $p<0.05$ was used to indicate significance (Landau and Everitt, 2004).

\section{Results and Discussion}

\section{Chemical analysis}

The chemical composition of dried saffron flour is shown in table (2). Data indicated that the saffron rich in protein $(11.87 \mathrm{~g})$, carbohydrate $(63.33 \mathrm{~g})$, fat $(4.97 \mathrm{~g})$, fiber $(5.61 \mathrm{~g})$, moisture $(9.44 \mathrm{~g})$ and ash (4.78g). (Carmona et al., 2006; Bell, 2008; Singla and Bhat, 2011; Zarinkamar et al., 2011; Samarghandian and Borja, 2014; Muzaffar et al., 2015).They found that, saffron stigmas contains carbohydrates, proteins, moisture, ash, fat, amino acids, minerals, starch and vitamins.

Table 2: Chemical composition of dried saffron flour (Crocus sativus $L$ ) dried powder (g/100g).

\begin{tabular}{lc}
\hline Contents & Saffron flour \\
\hline Ash(\%dm) & $4.78 \pm 0.03$ \\
Protein (\%dm) & $11.87 \pm 0.21$ \\
Carbohydrate (\%dm) & $63.33 \%$ \\
Moisture & $9.44 \pm 0.11$ \\
Fat & $4.97 \pm 0.03$ \\
Fiber & $5.61 \pm 0.10$ \\
\hline
\end{tabular}

Values are expressed as means \pm standard deviations (SD).

\section{Effect of saffron on body weight of obese rats}

From the above results, it is clear that, the best concentrations of saffron, were $5 \%$ saffron sensibility. Which had allow effect on $2 \%$ saffron.

Results in table (3) exhibit that, rats fed on high fat diet revealed a highly significant increased $(p<0.05)$ in the mean value of body weight as compared with negative control group. Treating obese rat with herbs showed a significant decreased $(\mathrm{p}<0.05)$ in body weight as compared with positive group .Rats fed on high fat diet and supplemented with $5 \%$ saffron had highly significant reduction in body weight than the other group that fed on saffron $(2 \%)$.

Table 3: Effect of Saffron (Crocus sativus) on body weight of obese rats

\begin{tabular}{lccccc}
\hline $\begin{array}{c}\text { Parameters } \\
\text { Groups }\end{array}$ & \multicolumn{1}{|c|}{ BBW (g) } & FBW (g) & BWG \% & $\begin{array}{c}\text { Feed Intake } \\
\text { (g/day/rat) }\end{array}$ & FER \\
\hline 1-Control (-ve) & $180 \pm 5^{\mathrm{a}}$ & $268.3 \pm 47.2^{\mathrm{a}}$ & $49.6 \pm 30^{\mathrm{a}}$ & 17.143 & $5.8 \pm 1.15^{\mathrm{a}}$ \\
2-Control (+ve) & $180 \pm 5^{\mathrm{a}}$ & $291.66 \pm 27.5^{\mathrm{a}}$ & $62.4 \pm 19.8^{\mathrm{a}}$ & 25.6 & $2.5 \pm 0.5^{\mathrm{b}}$ \\
3-Saffron (2\%) & $171.66 \pm 10.4^{\mathrm{a}}$ & $183.3 \pm 2.8^{\mathrm{b}, \mathrm{c}, \mathrm{d}}$ & $7 \pm 7.38^{\mathrm{b}, \mathrm{c}}$ & 16.9 & $9.8 \pm 0.76^{\mathrm{c}, \mathrm{e}}$ \\
4-Saffron (5\%) & $171.66 \pm 7.6^{\mathrm{a}}$ & $176.66 \pm 5.77^{\mathrm{b}, \mathrm{d}}$ & $6.81 \pm 1.9^{\mathrm{b}, \mathrm{c}}$ & 16.9 & $9 \pm 0.5^{\mathrm{c}, \mathrm{d}, \mathrm{e}}$ \\
\hline
\end{tabular}

- Values are expressed as means \pm SD

- Values at the same column with different letters are significant at $(\mathrm{P}<0.05)$.

- IBW : initial body weight

- FBW : Final body weight

- BWG: body weight gain

- FER: Feed intake ratio

The highest reduction in body weight was observed in the group fed on a combination of (5\% saffron) as compared to the other treated group. This effect was due to the specific bioactive components of saffron which components of stigma are carotenoids (crocin), glycoside (picrocrocin), 
volatile oil component (safranal) (Winterhalter and straubinger, 2000; Fernandez and pandalai, 2004) and flavonoids including quercetin (pitsikas et al., 2007).

\section{Effect of saffron on lipid profile of obese rats}

Effect of herb supplementation on serum level of total cholesterol, triglycerides (TG), high density lipoprotein cholesterol (HDL-c, LDL-c) and very low density lipoprotein cholesterol (VLDLc) in obese rats was presented in table (4). It could be noticed that, the control positive group was shown a significant increased $(\mathrm{P}<0.05)$ in the mean values of serum TC, TG, VLDL-c and LDL-c as compared with those of the control negative group. This increase was a result of feeding rats with high fat diet that induced obesity. Results in this table revealed that, all treated obese rats with saffron showed a significant decrease $(\mathrm{P}<0.05)$ in the mean values of serum $T C, T G$, VLDL-c and LDL-c as compared to positive control group. While HDL-c was revealed a significantly increased for all treated rats as compared to the corresponding value of control positive but still lower than control negative. Furthermore, treating obese rats with $5 \%$ saffron powder, caused a significant decreased $(\mathrm{P}<0.05)$ in serum TC and TG as compared to the group treated with $2 \%$ saffron. However, there were no significant changes in the mean values of TC and TG for the groups fed on $2 \%$ saffron. It was caused a high significant decreased $(\mathrm{P}<0.05)$ in the level of TC and TG as compared to positive group. On the contrary, results with slight decrease in serum TC were noticed in groups fed on herbs.

Moreover, rats fed on a combination with $(5 \%$ saffron $)$ had a significant decreased $(\mathrm{P}<0.05)$ in the level of TC compared to the rats fed on concentration herb $2 \%$ saffron. The highest decrease $(\mathrm{P}<0.05)$ in the level of TC and TG was clearly observed on the group fed on high fat diet and supplemented with a combination of ( $5 \%$ saffron) compared with other treated group. These results are in agreement with omid et al., (2019).

Table 4: Effect of Saffron on lipid profile of obese rats

\begin{tabular}{llllll}
\hline \multicolumn{1}{c}{ Parameters } & $\begin{array}{c}\text { Total } \\
\text { cholesterol } \\
\text { (mg/dl) }\end{array}$ & $\begin{array}{c}\text { Triglycerides } \\
(\mathbf{m g} / \mathbf{d l})\end{array}$ & $\begin{array}{c}\text { VLDL }-\mathbf{C} \\
\mathbf{( m g / d l )}\end{array}$ & $\begin{array}{c}\text { HDL - C } \\
\text { (mg/d) }\end{array}$ & $\begin{array}{c}\text { LDL - C } \\
\text { (mg/dl) }\end{array}$ \\
\hline 1-Control (-ve) & $119 \pm 6.5^{\mathrm{a}}$ & $84.67 \pm 12.2^{\mathrm{a}}$ & $17 \pm 2.44^{\mathrm{a}}$ & $40.33 \pm 3.21^{\mathrm{a}, \mathrm{c}}$ & $61.73 \pm 6.6^{\mathrm{a}, \mathrm{d}}$ \\
2-Control (+ve) & $248 \pm 15.7^{\mathrm{b}}$ & $194.67 \pm 6^{\mathrm{b}}$ & $39 \pm 1.2^{\mathrm{b}}$ & $38.33 \pm 5.5^{\mathrm{a}, \mathrm{c}}$ & $170.73 \pm 11.7^{\mathrm{b}}$ \\
3-Saffron (2\%) & $142.67 \pm 14^{\mathrm{c}}$ & $112.33 \pm 4^{\mathrm{c}}$ & $26.2 \pm 3.36^{\mathrm{c}}$ & $48.67 \pm 3^{\mathrm{b}}$ & $84.86 \pm 12^{\mathrm{c}, \mathrm{d}}$ \\
4-Saffron (5\%) & $130.33 \pm 2^{\mathrm{a}, \mathrm{c}}$ & $94 \pm 10.4^{\mathrm{a}, \mathrm{c}}$ & $19 \pm 2^{\mathrm{a}, \mathrm{d}}$ & $35.33 \pm 3.51^{\mathrm{a}}$ & $62.86 \pm 5^{\mathrm{a}, \mathrm{d}}$ \\
\hline
\end{tabular}

- Values are expressed as means $\pm \mathrm{SD}$

- Values at the same column with different letters are significant at $(\mathrm{P}<0.05)$

\section{Effect of saffron on kidney functions of obese rats}

The effect of supplementation with saffron on serum urea, uric acid and creatinine in obese rats was shown in table (5). That rats fed high fat diet revealed significant increased $(\mathrm{P}<0.05)$ in the mean value of serum urea, uric acid and creatinine of control positive group as compared with those of negative control group.

Table 5: Effect of Saffron on kidney functions of obese rats

\begin{tabular}{|c|c|c|c|c|}
\hline Groups & Parameters & Creatinine (mg/dl) & Urea (mg/dl) & Uric acid (mg/dl) \\
\hline 1-Control (-ve) & & $0.6 \pm 0.02^{\mathrm{a}}$ & $22.67 \pm 5.5^{\mathrm{a}}$ & $3.1 \pm 3^{\mathrm{a}}$ \\
\hline 2-Control (+ve) & & $0.71 \pm 0.09^{\mathrm{a}, \mathrm{c}}$ & $33.67 \pm 3.7^{b}$ & $3.9 \pm 0.41^{\mathrm{b}}$ \\
\hline 3-Saffron (2\%) & & $0.87 \pm 0.05^{\mathrm{b}}$ & $34.67 \pm 3.5^{\mathrm{c}}$ & $5.2 \pm 0.4^{\mathrm{c}}$ \\
\hline 4-Saffron (5\%) & & $0.71 \pm 0.08^{\mathrm{a}, \mathrm{c}}$ & $26.33 \pm 3.5^{\mathrm{a}, \mathrm{c}}$ & $3 \pm 0.25^{\mathrm{a}}$ \\
\hline
\end{tabular}

- Values are expressed as means \pm SD.

- Values at the same column with different letters are significant at $(\mathrm{P}<0.05)$

The supplementation with saffron showed a significant decreased $(\mathrm{P}<0.05)$ in serum urea, uric acid and creatinine as compared to positive control group. Simple had significant changes were noticed in serum urea between the groups fed on high fat diet and supplemented with $2 \%$ saffron. The highest reduction in serum urea was recorded in rats fed on the $5 \%$ saffron. These results are in agreement with Alireza et al., (2017). They stated that, saffron improved renal protection BUN and uric acid 
reductions were significant within the saffron. In addition, saffron is a safe spice with the minimum toxicity on the body normal cells.

\section{Effect of saffron on liver functions of obese rats}

The effect of supplementation with herb on ALT, and AST in obese rats was tabulated in table (6). It could be discerned that, rats fed on high fat diet had a significant increase $(\mathrm{P}<0.05)$ in the level of serum ALT and AST compared to the negative group.

Moreover, a significant changes were noticed in the level of serum AST among all the treated group but the group fed on 2\% saffron had highly increase in AST except for the group fed on 5\% saffron had highly significant decreased. On the other hand, there were no significant changes in the level of ALT between the group fed on high fat diet and supplemented with $2 \%$ saffron and the group fed on the same diet had highly increase in ALT except for the group fed on 5\% saffron. Furthermore, the levels of AST and ALT were highly significant among all groups fed on high fat diet and supplemented with the low concentration of herbs but still higher than control negative group for ALT and AST. Based on the Alireza et al., (2017), study liver protective effects of saffron have been demonstrated at acetaminophen induced liver stress. In the present study, saffron has reduced ALT and AST.

Table 6: Effect of Saffron on liver functions of obese rats

\begin{tabular}{|c|c|c|}
\hline Groups & 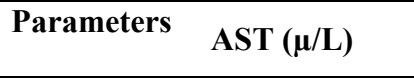 & $\operatorname{ALT}(\boldsymbol{\mu} / \mathbf{L})$ \\
\hline 1-Control (-ve) & $19.33 \pm 2.517^{\mathrm{a}}$ & $21 \pm 3^{\mathrm{a}}$ \\
\hline 2-Control (+ve) & $61.67 \pm 3.512^{b}$ & $81 \pm 3^{b}$ \\
\hline 3-Saffron (2\%) & $48.67 \pm 2^{\mathrm{c}, \mathrm{d}}$ & $55.67 \pm 5.86^{\mathrm{d}}$ \\
\hline 4-Saffron (5\%) & $42 \pm 5.56^{\mathrm{c}}$ & $44.33 \pm 3.512^{\mathrm{c}, \mathrm{e}}$ \\
\hline
\end{tabular}

- AST : Aspartate amino transferase.

- ALT : Alanine amino transferase.

- Values are expressed as means $\pm \mathrm{SD}$.

- Values at the same column with different letters are significant at $(\mathrm{P}<0.05)$.

\section{Effect of saffron on serum glucose level}

The effect of supplementation of saffron on glucose levels was tabulated in table (7). It could be observed that, rats fed on high fat diet revealed a highly significant increased in mean value of serum glucose, compared with negative control group. The supplementation with saffron showed a significant decreased $(\mathrm{P}<0.05)$ in serum glucose compared to positive control.

There was a great changes in serum glucose between the group fed on herb. At the same time there was a significant increased among the group fed on high fat diet and supplemented with $2 \%$ saffron. It was observed that, there were significant differences in glucose level among the group which fed on high fat diet and supplemented with $2 \%$ saffron. The highest reduction in serum glucose was observed in the group fed on 5\% saffron. These results are in agreement with Efentakis et al. (2017), they stated that the effect of saffron reduction of glucose levels, serum glucose , insulin resistance and glucose profile.

Table 7: Effect of Saffron on serum glucose levels of obese rats

\begin{tabular}{|c|c|c|}
\hline Groups & Parameters & Glucose (mg/dl) \\
\hline 1-Control (-ve) & & $77 \pm 8.185^{\mathrm{a}}$ \\
\hline 2-Control (+ve) & & $173.67 \pm 13.86^{\mathrm{b}}$ \\
\hline 3-Saffron (2\%) & & $116 \pm 6.24^{\mathrm{c}}$ \\
\hline 4-Saffron (5\%) & & $106.67 \pm 6.8^{\mathrm{c}, \mathrm{e}}$ \\
\hline
\end{tabular}

- Values are expressed as means $\pm \mathrm{SD}$

- Values at the same column with different letters are significant at $(\mathrm{P}<0.05)$. 


\section{Effect of saffron on relative organs weight of obese rats \\ 7.1. Relative liver weight}

The effect of supplementation of saffron on liver weight was tabulated in table (8). The obtained data showed that rats fed high fat diet caused a significant increased $(\mathrm{P}<0.05)$ in liver weight compared to negative control group. Feeding obese rats on a diets containing different herb revealed a significant decreased $(\mathrm{P}<0.05)$ in liver weight compared to positive control group. It was observed that, there were a significant differences in liver weight between the group fed on $2 \%$ and positive control group while, saffron group fed on $5 \%$ saffron caused reduction in liver weight compared with other groups.

\subsection{Relative spleen weight}

Results in the table (8) showed that, feeding rats on a high fat diet caused a significant increased $(\mathrm{P}<0.05)$ in spleen weight, compared to negative control group. group treated with had a significant decreased $(\mathrm{P}<0.05)$ in spleen weight compared with positive control group, there were no significant differences among all the groups fed on high fat diet and fed on $2 \%$ saffron except for the group fed on $5 \%$ saffron was the highest reduction in spleen weight.

\subsection{Relative kidney weight}

The effect of saffron on kidney weight was tabulated in table (8).

The obtained data showed that, rats fed on high fat diet caused a significant increased $(\mathrm{P}<0.05)$ in kidney weight compared to negative control group. Groups treated with herbs or in kidney weight compared to positive control group except for the group that fed on $5 \%$ saffron caused a significant decreased in kidney weight compared to positive control.

\subsection{Relative heart weight}

In respect of heart results in the same table (8). It showed that, feeding rats on high fat diet caused no significant increased $(\mathrm{P}<0.05)$ in heart weight compared to negative control group a. Feeding obese rats on a diet containing different herbs revealed significant decreased $(\mathrm{P}<0.05)$ in heart weight compared to positive control group. It was observed that there were no significant differences in heart weight among the group fed on $2 \%$ saffron, $5 \%$ saffron.

Table 8: Effect of Saffron on relative organs weight of obese rats

\begin{tabular}{|c|c|c|c|c|}
\hline \multirow[b]{2}{*}{ Groups } & Parameters & \multirow[b]{2}{*}{ Spleen \% } & \multirow[b]{2}{*}{ Kidney \% } & \multirow[b]{2}{*}{ Heart \% } \\
\hline & Liver \% & & & \\
\hline 1-Control (-ve) & $4.12 \pm 0.056^{\mathrm{a}}$ & $0.15 \pm 0.005^{\mathrm{a}, \mathrm{c}}$ & $1.53 \pm 0.255^{\mathrm{a}}$ & $0.3 \pm 0.005^{\mathrm{a}}$ \\
\hline 2-Control (+ve) & $7.82 \pm 0.11^{b}$ & $0.4 \pm 0^{\mathrm{b}}$ & $2.36 \pm 0.15^{\mathrm{b}}$ & $0.32 \pm 0.01^{\mathrm{b}}$ \\
\hline 3 -Saffron $(2 \%)$ & $3.88 \pm 0.19^{\mathrm{a}}$ & $0.25 \pm 0.05^{\mathrm{a}, \mathrm{b}}$ & $1.16 \pm 0.084^{\mathrm{c}}$ & $0.23 \pm 0.005^{\mathrm{c}}$ \\
\hline 4-Saffron $(5 \%)$ & $3.68 \pm 0.061^{\mathrm{a}}$ & $0.091 \pm 0.128^{\mathrm{c}}$ & $1.22 \pm 0.18^{\mathrm{c}}$ & $0.2 \pm 0^{\mathrm{d}}$ \\
\hline
\end{tabular}

- Values are expressed as means $\pm \mathrm{SD}$

- Values at the same column with different letters are significant at $(\mathrm{P}<0.05)$.

\section{Conclusion}

The mentioned above results suggested that saffron supplementation may provide beneficial effects in body weight reduction as well as improving lipid profile and liver function and kidney function and serum glucose in obese rats.

\section{References}

A.O.A.C. Association of Official Analytical chemists International, 2005. Official methods of International, $18^{\text {th }}$ Edition gaither sburg. Maryland, USA, AOAC International, -101.81.

Akhondzadeh, M.S., M.H. Sabet, M. Harirchian, H. Togha, R. Cheraghmakani, M.H. Hejazi, R. Yousefi, A. Alimardani, F. Jamshidi, A. Zare and A. Moradi, 2010. Saffron in the treatment of patients with mild to moderate Alzaheimer disease: a 16- week, randomized and placebo controlled trial, J. Clin. Pharm Ther., 35(5):581-588. 
Alireza, M., G. Shima, B. Vida, H. Nagmeh, S. Elham, D. Zhaleh, M. Mahmood, R. Alireza, M. Abolghassem and A. Shahin, 2017. The effect of saffron (Crocus sativus L.) hydro-alcoholic extract on liver and renal functions in type 2 diabetic patients: a double-blinded randomized and placebo control trial. Journal of Nutrition and Intermediary Metabolism, 9:6-11.

Allain, C.C., C.S. Chan, W.F.U. Richmond and L.S. Poon, 1974. Enzymatic determination of total serum cholesterol: Clinical Chemistry,20(4): 470-475.

Assimopoulou, A.N., Z. Sinakos, and V.P. Papageorgiou, 2005. Radical scavenging activity of Crocus sativus L. extract and its bioactive constituents. Phytother. Res., 19: 997-1000.

Azain, M.J., D.B. Hausman, M.B. Sisk, W.P. Flatt and D.E. Jewell, 2000. Dietary conjugated linoleic acid reduces rat adipose tissue cell size rather than cell number. J. Nutr., 130:1548-1554.

Bell, I.N., 2008. Moisture effects on foods chemical stability. In: Barbosa-cano-vas(Eds.) water activity in foods: fundamentals and applications. Blackwell publishing Ltd, oxford, 137-198.

Berth, M. and J. Delanghe, 2004. Protein precipitation as a possible important pitfall in the clinical chemistry analysis of blood samples containing monoclonal immunoglobulins: 2 case reports and a review of literature, Acta Clin. Belg., 59: 263.

Bolhassani, A., A. Khavari and S.Z. Bathaie, 2014. Saffron and natural carotenoids: biochemical activities and anti-tumor effects, Biochim. Biophys. Acta. $184520 \mathrm{e} 30$.

Brasil, R., N. and D.E. de abril, 1999. Aprova o Regulamento Técnico que Estabelece as Diretrizes Básicas para Análise e Comprovação de Propriedades Funcionais e ou de Saúde Alegadas em Rotulagem de Alimentos. Diário Oficial da República Federativa

Carmona, M., A. Zalacain, and G.L. Alonso, 2006. The plant. In: The chemical composition of saffron: color, taste and aroma. First ed. Albacete, Editorial Bomarzo SL, 1-32.

Chen, Y., H. Zhang, X. Tian, C. Zhao, L. Cai, Y. Liu, L. Jia., H.X. Yin, and C. Chen, 2008. Antioxidant potential of crocins and ethanol extracts of Gardenia jasminoides ELLIS and Crocus sativus L. A relationship investigation between antioxidant activity and crocin contents. Food Chem., 109(3): 484-492.

Christodoulou, E., N.P. Kadoglou, P.N. Kostomitso, and G. Valsami, 2015. Saffron: a natural product with potential pharmaceutical applications. J. Pharm. Pharmacol., 67(12): 1634-1649.

De Matos, F.F., M.C. Bertoluci and C. Reis, 2011. Serotonin and hypothalamic control of hunger: a review. Rev. Assoc. Med. Bras., 57(1): 74-77.

Dunn, D., 2015. Addressing the Problem of Obesity. AORN J., 102: 111-115.

Efentakis P., A. Rizakou, E. Christodoulou, M.G.A. Chatzianastasiou , L.R. Lopez, and E. Balafas, 2017. Saffron (Crocus sativus) NPE Nutrition, Metabolism and cardiovascular diseases, 27(10):919-929.

Fernadez, J.-A. and S. Pandalai, 2004. Biology, biotechnology and biomedicine of saffron. Recent Res. Dev. Plant Sci., 127-159.

Fritzberg, A.R., S. Kasina, D. Eshima, and D.L. Johanson, 1986. Journal of Nuclear medicine: official Publication, Society of Nuclear Medicine, 27(1):111-116.

Gainer, J.L., D.B. Rudolph and D.L. Caraway, 1993. The effect of crocetin on hemorrhagic shock in rats. Circ. Shock, 41:1-7.

Gout, B., C. Bourges, and D.S. Paineau, 2010. Satiereal, a Crocus sativus L extract, reduces snacking and increases satiety in a randomised placebo-controlled study of mildly overweight, healthy women. Nutr. Res., 30(5): 305-313.

Gray, D.E., G.E. Rottinghaus, H.E. Garrett, and S.G. Pallardy, 2000. Simultaneous determination of the predominant hyperforins and hypericins in St. John swort (Hypericum perforatum L.) by liquid chromatography. J AOAC Int., 83:944-949.

Haidari, F., E. Shirbeigi, Ch. Makan and M. Mohammadshahi, 2014. Association of dietary patterns with body mass index, waist circumference, and blood pressure in an adult population in Ahvaz, Iran. Saudi Med. J., 35: 967-974.

Imenshahidi, M., H. Hosseinzadeh, and Y. Javadpour, 2010. Hypotensive effect of aqueous saffron extract (Crocus sativus L.) and its constituents, safranal and crocin, in normotensive and hypertensive rats. Phytother. Res., 24(7): 990-994. 
Interference testing in clinical chemistry, 2005. Approved Guideline - second edition. CLSI (NCCLS) document EP7 -A2, 25(27).

Jennigs,F.W., P.K. Murray, M. Murray, and G.M. Urquhart, 1974. Anaemia in trypanosomiasis: studies in rats and mice infected with trypanosome brucie. Research in Veterinary Science, 16(1):70-76

Kanakis, C.D., P.A. Tarantilis, H.A. Tajmir Riahi, and M.G. Polissiou, 2007. Crocetin, dimethylcrocetin and safranal bind human serum albumin: stability and antioxidative properties. J. Agric. food Chem., 55(3): 970- 7.

Landau, S. and B.S. Everitt, 2004. Analysis of variance I: One Way Designs; fecundity of fruit flies, finger tapping, and female social skills, In: A Hand book of statistical Analyses using SPSS. Champan and Hall /Crc, 145-149

Maryam, M., A. Azrina, M. Norhafizah, N. Barakatun, Y. Mohd, and K. Huzwah, 2017. Saffron extract and crocin reduced biomarkers associated with obesity in rats fed a high - fat diet .mal. j. nutr., 23 (1):117-127.

Mohajeri, D., G. Mousavi, and Y. Doustar, 2009. Antihyperglycemic and pancreas-protective effects of Crocus sativus L. (saffron) stigma ethanolic extract on rats with alloxan-induced diabetes. J. Biol. Sci., 9(4): 302-310.

Mohammadshahi, M., F. Haidari, M. Karandish, S. Ebrahimi, and M. H. Haghighizadeh, , 2014. A Randomized Clinical Trial of Nutrition Education for improvement of Diet Quality and Inflammation in Iranian Obese Women. J. Nutr. Metab.,605782.

Molina, R. V., M. Valero, Y. Navarro, J. L. Guardiola, and A. García Luis, 2005. Temperature effects on flower formation in saffron (Crocus sativus L.). Scientia Horticulturae, 103, $361 \mathrm{e} 379$.

Muzaffar, S., S.A. Rather, K.K. Zaman and R. Akhter, 2015. Nutritional composition and in vitro antioxidant properties of two cultivars of indian saffron. Food Mesure., 10:185-192.

Nescatelli, S., F. Carradori, V. Marini, R. Caponigro, C. Bucci, A. De Monte, L. Mollica, M. Mannina, C.T. Ceruso, and D. Supuran, 2017. Secci, Geographical characterization by MAE-HPLC and NIR methodologies and carbonic anhydrase inhibition of Saffron components, Food Chem, $221855-863$.

NRC, National Research Council, 1993. Pesticides in the Diets of Infants and children. Washington DC: National Academy Press.

Omid, S.S., N. Noushin, M. Alireza, C. Saeed, and A. Zatollah, 2019. A Student Research Committee, Lorestan University of Medical Sciences, Khorramabad, Iran Prevention of Metabolic Disorders Research Center, Research Institute for Endocrine Sciences, Shahid Beheshti University of Medical Sciences, Tehran, Iran.

Pitsikas, N., S. Zisopoulou, P.A. Tarantillis, Ch.D. Kanakis, M.G. Polissiou, and N. Sakellaridis, 2007. Effects of the active constituents of saffron on recognition and spatial rats memory .Behavioural brain Res., 183:141-146.

Ramadan, A., G. Soliman, S.S. Mahmoud, S.M. Nofal, and R. F. Abdel Rahman, 2010. Evaluation of the safety and antioxidant activities of Crocus sativus and propolis ethanolic extracts. Saudi Chemical Society, 16, $13 \mathrm{e} 21$.

Riose, J.L., M. Recio, R.M. Ginger, and S. Manz, 1996. An update review of saffron and its active constituents. Phytother. Res., 10: 89-93.

Rubio-Moraga, A., A. Trapero, O. Ahrazem, and L. Gomez-Gomez, 2010. Crocins transport in saffron : The long road from a senescent stigma to a new born corm.phytochem,71:1506-1513.

Samarghandian, S. and A. Borja, 2014. Anticarcinogenic effect of saffron and its ingredients. Pharmacognosy Res., 6(2):99-107.

Single, R.K. and G.V. Bhat, 2011. Crocin: an overview. Indo Global Journal of Pharmaceutical Sciences, 1(4):281-286.

Steinberg, D., 1981. Metabolism of lipoproteins at the cellular level in relation to atherogenesis. In Lipoproteins, Atherosclerosis and Coronary Heart Diseases, 1(2):31-48.

Terpstra, A.H.M., J.A. Lapre, H.T. DeVries, and A.C. Beynen, 1998. Dietary pectin with high viscosity lower plasma and liver cholesterol concentration and plasma cholesteryl ester transfer protein activity in hamsters. J. Nutr., 128:1944-9. 
Trantilis, P.A., G. Tsoupras and M. Polissiou, 1995. Determination of saffron (Croucus sativus L.) components in crude plant extract using high performance liquid chromatograghy-extract using high-performance liquid chromatograghy-UV-visible photodiode-array detection-mass spectrometry. J. Chromatogr, 699: 107-118.

Vassault, A., 1986. Ann. Biol. Clin. 44: 686.

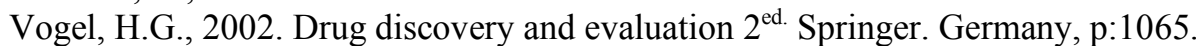

Winterhalter, P. and M. Straubinger, 2000. Saffron; renewed interest in an ancient spice. Food Rev.Int.,16, 39-59.

Xi, L., Z. Qian, X. Shen, N. Wen, and Y. Zhang, 2005. Crocetin prevents dexamethasone-induced insulin resistance in rats. Planta Med., 71: 917-22.

Young, D.S., 2001. Effects of disease on clinical lab .Tests, $4^{\text {th }}$ ed AACC.

Zarinkamar, F., S. Tajik and S. Soleimanpour, 2011. Effects of altitude on anatomy and concentration of crocin, picrocrocin and safranal in crocus sativus L.,. Crop Science, 5(7):831-838. 